\title{
Reproductive traits of Macrobiotus hufelandi during a long-term field study with notes on Paramacrobiotus richtersi and Diphascon pingue (Eutardigrada)
}

\author{
Rolf SCHUSTER, ${ }^{1}$ Hartmut GREVEN ${ }^{2 *}$ \\ ${ }^{1}$ Schule Birklehof, Birklehof 11, D-79856 Hinterzarten, Germany; ${ }^{2}$ Institut für Zellbiologie der Universität Düsseldorf, Universitätsstraße 1, \\ D-40225 Düsseldorf, Germany \\ *Corresponding author: grevenh@uni-duesseldorf.de
}

\begin{abstract}
We studied reproductive traits in populations of the eutardigrade species Macrobiotus hufelandi, Paramacrobiotus richtersi, and Diphascon pingue from a carpet of the moss Rhytidiadelphus squarrosus in the Black forest, Germany, over a period of 53 months. Specimens were fortnightly extracted, measured, and divided into dead and living individuals. The living specimens were divided into juveniles, ovigerous females (i.e. females with mature eggs and immature, but vitellogenetic eggs), and females with undifferentiated oocytes. Males were never found during the investigation period. For the most abundant species, M. hufelandi, it was shown that i) ovigerous females were found throughout the year; ii) reproductive activity (expressed as the percentage of ovigerous females in the total population) was highest from January to June, but peaks in these months varied considerably within the investigation period; iii) development of eggs may be considerably delayed compared with data obtained from cultures; iv) presence of ovigerous adults and juveniles was nearly opposite, i.e. the more adults the fewer juveniles were found, and a maximum of adults was followed by a maximum of juveniles with some delay and vice versa; v) number of oocytes, as well as length and percentage of ovigerous females relative to the total number of specimens appeared to be negatively correlated, whereas percentages of juveniles $(<260 \mu \mathrm{m}$ in length) appeared to be positively correlated with temperature. Other correlations included humidity (number of oocytes, negative; percentage of juveniles, positive) and the sum of hours of sunshine (length and percentage of ovigerous females, negative; percentage of juveniles, positive). The relatively low numbers of $\mathrm{P}$. richtersi and $\mathrm{D}$. pingue collected during the investigation period did not allow a more detailed analysis, but here as well ovigerous females were found throughout the year.
\end{abstract}

Key words: Eutardigrada, reproduction, long-term study, natural population.

\section{INTRODUCTION}

Long-term studies, preferably $\geq 5$ years, of population dynamics of moss inhabiting micrometazoans may provide a more reliable insight into factors affecting their distribution and abundance, such as climatic conditions or cyclic patterns that may be dependent or independent from the climate. Most studies concerning population dynamics of limnoterrestrial tardigrades cover relatively short periods and represent more or less isolated observations (Marcus, 1929; Franceschi et al., 1962-1963; Hallas and Yeates, 1977; Schütz, 1987; Grabowski, 1995; Guidetti et al., 1999). Only a few studies cover a period of more than one year (Morgan, 1977: 28 months; Jennings, 1979: 21 months; Schuster and Greven, 2007: 54 months) and even rarer are studies that include data on reproduction, e.g. the number of eggs in a clutch in the case of species that lay their eggs in the shed exuvia such as Echiniscus testudo (Doyère, 1840) (Morgan, 1977), Milnesium tardigradum Doyère, 1840 (Schütz, 1987), and the aquatic Pseudobiotus kathmanae Nelson, Marley and Bertolani, 1999 (Kathman and Nelson, 1987; for species determination see Nelson et al., 1999). A quantitative analysis of free eggs laid on the substrate is more difficult due to the lack of reliable quantitative sampling methods.
Generally, studies on population dynamics either revealed clear annual fluctuations of population densities with varying peaks, primarily in spring and autumn (certain species seem to completely disappear in some months), fluctuations seemingly not exactly related to seasons, or no distinct fluctuations (Schütz, 1987). Reasons for that are manifold, but largely unexplored. They may include mesoclimatic conditions, density-dependent (competition, predation, parasitism) and density-independent factors (e.g. microclimatic data, oxygen levels, and $\mathrm{pH})$ as well as species-specific differences. In the absence of microclimatic measurements (Schuster et al., 2009), population parameters usually were correlated with mesoclimatic data (temperature, humidity, precipitation), but results often appear inconsistent and not easy to interpret (Franceschi et al., 1962-1963; Morgan, 1977; Grabowski, 1995; Schuster and Greven, 2007).

Schuster and Greven (2007) presented data of a 54month field survey showing that the tardigrade community found in the moss Rhytidiadelphus squarrosus (Hedw.) Warnst was relatively robust over the years. The eutardigrades Macrobiotus hufelandi C.A.S. Schultze, 1834, Paramacrobiotus richtersi (Murray, 1911) and Diphascon pingue (Marcus, 1936) emerged as the most abundant 
species within the community and occurred consistently in all months (frequency $100 \%$ ) during this time. Especially M. hufelandi showed an annual cycle with a basically unimodal pattern. Mean number of tardigrades was negatively (M. hufelandi) or positively (P. richtersi, D. pingue) correlated with the rainfall and positively correlated with the temperature (M. hufelandi) (Schuster and Greven, 2007). The present paper broadens this study by adding some new life history data, primarily of $M$. hufelandi, which have been indirectly obtained during 53 months within the above mentioned period by counting and measuring juveniles and ovigerous females and the number of eggs they carried.

\section{METHODS}

\section{Study site, sampling and species handling}

The study site was a lawn (located in Hinterzarten, Black forest, Germany; 47.9 N, $8.1 \mathrm{E}$; $880 \mathrm{~m}$ asl) covered by the moss $R$. squarrosus (Figs. 1a, b). From March 2000 to July 2004 (except July 2003 and August in all years) a total of 576 moss samples of approx. $1.8 \mathrm{~cm}^{3}$ were cored every two weeks from six adjacent sectors (approx. $2.3 \mathrm{~m}^{2}$ ) of the lawn. Tardigrades were extracted from the samples within $36 \mathrm{~h}$. Samples were soaked in tap water, and tardigrades were collected using a pipette and a stereoscope (Schuster and Greven, 2007). Each individual was carefully checked and the species determined using a compound microscope (magnification 400 to $1000 \times$ ). We never found clearly identifiable males with spermatozoa among the specimens, suggesting the presence of parthenogenetic populations (Schuster and Greven, 2007). The absence of males has been previously noted for $M$. hufelandi from a nearby area (Bertolani and Rebecchi, 1993) and from Russia (Bis- erov, 1990), and for some populations of P. richtersi in Italian localities (Bertolani, 1971, 1975). The specimens of each species were classified as i) dead individuals; ii) juveniles [ $<260 \mu \mathrm{m}$ in length: $M$. hufelandi; $<350 \mu \mathrm{m}$ in length: P. richtersi; and $<180 \mu \mathrm{m}$ in length: $D$. pingue (in individuals of these sizes oocytes were not found)]; and iii) specimens larger than juveniles (adults). The latter were classified as specimens with undifferentiated oocytes, and as gravid females with mature (after vitellogenesis) and immature oocytes (i.e. during vitellogenesis). Generally, the largest eggs completely filling the ovary were considered as mature. In $M$. hufelandi and P. richtersi occasionally the typical projections of the chorion closely abutting on the chorion were seen. Immature oocytes were already enlarged, but did not entirely fill out the ovary. From the living females we measured the body length and counted the number of oocytes (immature and mature) per female. For that purpose females were individually observed on a slide under the microscope (magnification 400x). The water between the cover slip and glass slide was cautiously removed by a piece of filter paper until the forward movement of the specimens was considerably reduced; then the body length, i.e. the distance from the anterior end of the head to the junction of the fourth pair of legs, was measured with a stage micrometer. Certainly, this measuring technique is deficient, but it allowed an overall useful estimation of length of a considerable number of specimens in an acceptable amount of time.

\section{Abiotic parameters and statistics}

Mesoclimatic data (temperature, rainfall, sunshine and atmospheric humidity) were obtained from the climatic
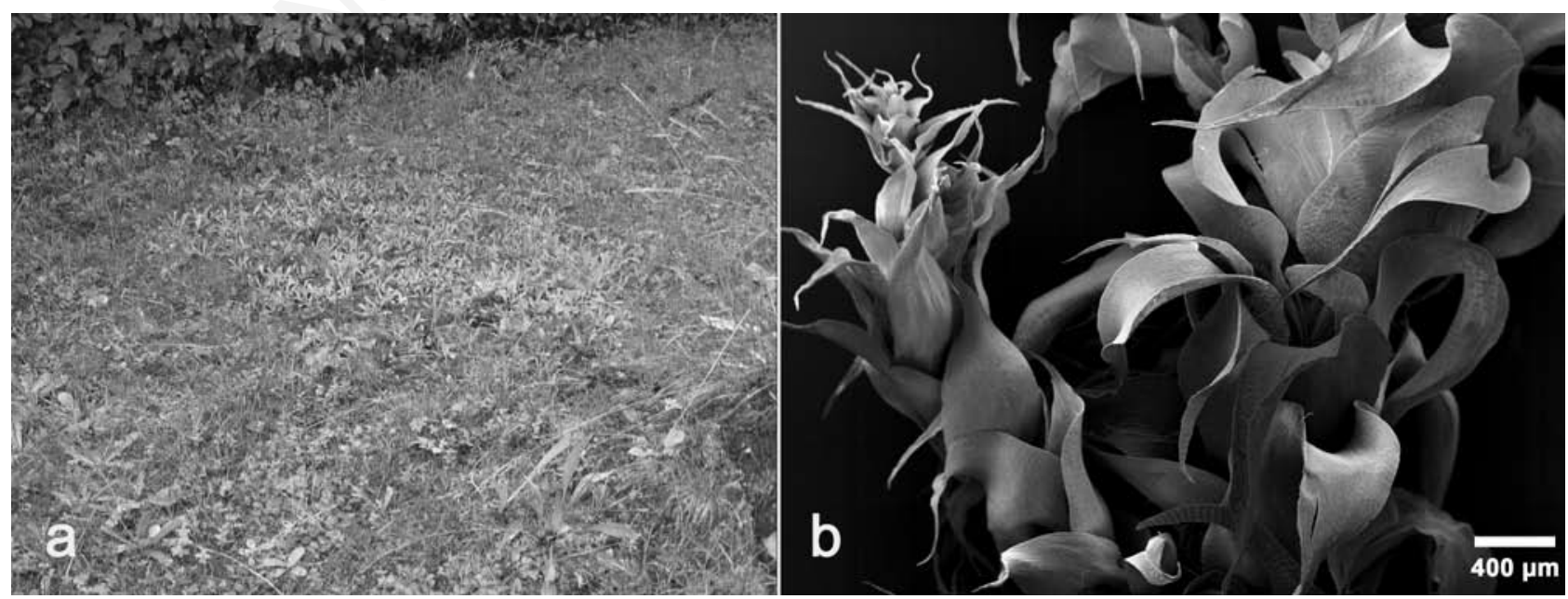

Fig. 1. a) Study site covered by the moss Rhytidiadelphus squarrosus; b) the moss in dried condition (scanning electron microscopymicrograph). 
station Hinterzarten (Deutscher Wetterdienst) $2 \mathrm{~km}$ from the site of investigation. Three values per day were averaged monthly (temperature, humidity) or summed up (rainfall) including August, resulting in 53 values. In addition, temperature, humidity, rainfall (one value per day) and average number of hours of sunshine 10,20 and 30 days before sampling were correlated with the several parameters [number of oocytes (immature, mature) with the number of juveniles] determined using the Spearman rank correlation (Backhaus et al., 1966).

Analyses were performed using WinSTAT ${ }^{\circledR}$ (R. Fitch Software D79189; WinSTAT, Bad Krozingen, Germany). Body lengths of the gravid females collected in early spring time (February, March, April) of all years (data of February 2000 were not available) and in autumn (September, October, November) were compared by an independent t-test.

\section{RESULTS}

\section{Temperature, rainfall, and humidity}

Monthly mean temperature, rainfall, and atmospheric humidity during the investigation period are shown in Fig.
$2 \mathrm{a}$ and $2 \mathrm{~b}$. There were heavy frosts in January 2002 , in winter 2003 and 2004, with warmer summers in 2002 and 2003 (Fig. 2a), exceeding the mean for many years (not pictured). Temperatures below the freezing point were to some extent buffered by snow cover. Therefore, the period in which tardigrades were inactive due to extreme low temperatures (e.g. December/January 2002) was relatively short, and at most dates in the winter, tardigrades were probably active. Mean rainfall varied considerably and was on average 1588 $\mathrm{mm}$ per year (Fig. 2a and 2b). However, comparing total rainfall (in $\mathrm{mm}$ ) per year with the mean for many years, a clear drop was seen in 2003, and particularly in 2004. Atmospheric humidity varied between 66 and $91 \%$ over the months. In the previous article, rainfall for June to October 2001 was erroneously underestimated by a power of ten (Fig. 2 in Schuster and Greven, 2007).

\section{Absolute numbers of specimens and their reproductive state}

Tab. 1 summarises the total number of specimens per species, which were collected during the investigation period, their reproductive state (juvenile, immature adult,
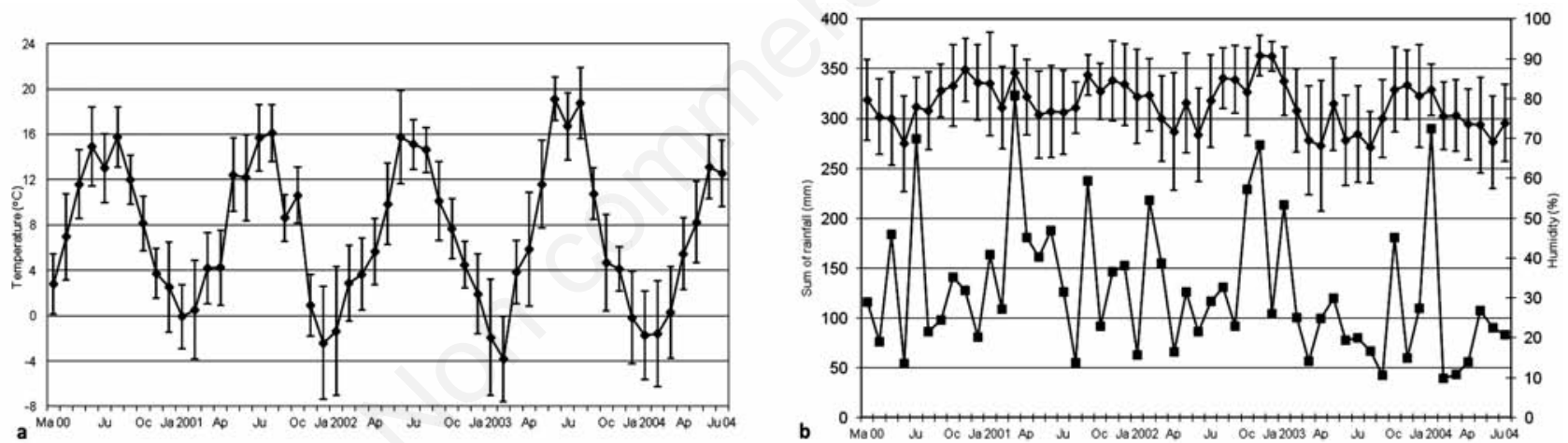

Fig. 2. a) Monthly temperature (mean \pm 1 standard deviation) from March 2000 to July 2004 ( $n=53$ ); b) monthly summed up rainfall (squares) and atmospheric humidity (diamonds) (mean \pm 1 standard deviation) from March 2000 to July 2004 ( $\mathrm{n}=53$ ).

Tab. 1. Total number of individuals per tardigrade species extracted from March 2000 to July 2004 and number and percentage of the different states distinguished.

\begin{tabular}{|c|c|c|c|}
\hline & Macrobiotus hufelandi & Paramacrobiotus richtersi & Diphascon pingue \\
\hline $\begin{array}{l}\text { Total number of individuals } \\
\text { Ovigerous } 99\end{array}$ & $\begin{array}{c}10,389 \\
3200(30.80 \%)\end{array}$ & $\begin{array}{c}3118 \\
416(13.34 \%)\end{array}$ & $\begin{array}{c}2278 \\
600(26.34 \%)\end{array}$ \\
\hline $\begin{array}{l}\text { Measured ovigerous }+9+ \\
\text { Immature } \\
\text { Mature } \\
\text { Juveniles }\end{array}$ & $\begin{array}{c}3040 \\
1907 \\
1133 \\
2018(19.42 \%)\end{array}$ & $\begin{array}{c}381 \\
170 \\
211 \\
1168(37.46 \%)\end{array}$ & $\begin{array}{c}470 \\
255 \\
215 \\
261(11.46 \%)\end{array}$ \\
\hline Dead specimens & $1057(10.17 \%)$ & $269(8.63 \%)$ & $155(6.80 \%)$ \\
\hline 우우 with undifferentiated gonads & $4114(39.60 \%)$ & $1265(40.57 \%)$ & $1262(55.4 \%)$ \\
\hline
\end{tabular}

ofemale. 
mature adult), and their percentage relative to the total number of collected specimens. Macrobiotus hufelandi was the most abundant species followed by $P$. richtersi and $D$. pingue. The percentage of juveniles was strikingly high in P. richtersi.

\section{Body length of ovigerous specimens, frequency of size classes and number of oocytes}

The body length of ovigerous females of all three species fluctuated throughout the investigation period with peaks that do not seem to follow a distinct pattern (not shown). However, when comparing the body lengths of the ovigerous females collected in early spring with those of females found in autumn, females of M. hufelandi and $D$. pingue appeared to be larger in spring (M. hufelandi: number of animals in spring $=996$, body length $=420 \pm 50 \mu \mathrm{m}$; number of animals in autumn $=492$; body length $=400 \pm 52 \mu \mathrm{m}, \mathrm{P}<0.01 ; D$. pingue: number of animals in spring $=132$, body length $=240 \pm 21 \mu \mathrm{m}$; number of animals in autumn $=124$, body length $=225 \pm 19 \mu \mathrm{m}$, $\mathrm{P}<0.01$ ), whereas in $P$. richtersi (number of animals in spring $=97$, body length $=615 \pm 73 \mu \mathrm{m}$; number of animals in autumn $=86$, body length $=630 \pm 92 \mu \mathrm{m}, \mathrm{P}>0.01$ ) no significant differences were detected.

Generally, length of ovigerous $M$. hufelandi specimens with immature oocytes ranged from 245 (a single individual of this size with one oocyte) to $570 \mu \mathrm{m}$ (ten oocytes) and that of specimens with mature oocytes from 280 (one oocyte) to $545 \mu \mathrm{m}$ (eight oocytes). The same data for $P$. richtersi are 450 (one oocyte) to $790 \mu \mathrm{m}$ (15 oocytes) (immature) and 400 (one oocyte) to $805 \mu \mathrm{m}$ (17 oocytes) (mature), and for $D$. pingue 195 (one oocyte) to $280 \mu \mathrm{m}$ (four oocytes) (non-mature) and 190 (one oocytes) to $280 \mu \mathrm{m}$ (four oocytes) (mature). For convenience we defined six $50 \mu \mathrm{m}$ (M. hufelandi, P. richtersi) and five $20 \mu \mathrm{m}(D$. pingue) size classes of ovigerous females, showing that the majority of specimens was in a middle range of their specific body length, i.e. 350-500 $\mu \mathrm{m}$ (M. hufelandi), 550-650 $\mu \mathrm{m}$ (P. richtersi), and 200-260 $\mu \mathrm{m}$ (D. pingue) (Fig. 3).

Number of oocytes per female varied considerably throughout the years, but seemed to reach maxima in the first half of the year, at least in $M$. hufelandi and $P$. richtersi (Fig. 4), which roughly coincides with the larger size of $M$. hufelandi in some of these months (see above).

Generally, there was a significant positive correlation (Spearman, $\mathrm{P}<0.01$ ) between the body length of the females of the three species and the number of oocytes, independent of their oogenetic stage.

The mean numbers of immature and mature oocytes were respectively $3.6 \pm 1.9(\mathrm{n}=1907)$ and $3 \pm 1.5(\mathrm{n}=1133)$ in M. hufelandi; $6.12 \pm 3.72(\mathrm{n}=170)$ and $4.21 \pm 2.77$ $(\mathrm{n}=211)$ in $P$. richtersi, and $2.29 \pm 1.12(\mathrm{n}=255)$ and $1.91 \pm 0.83(\mathrm{n}=215)$ in $D$. pingue. Differences were significant $(\mathrm{P}<0.01)$.
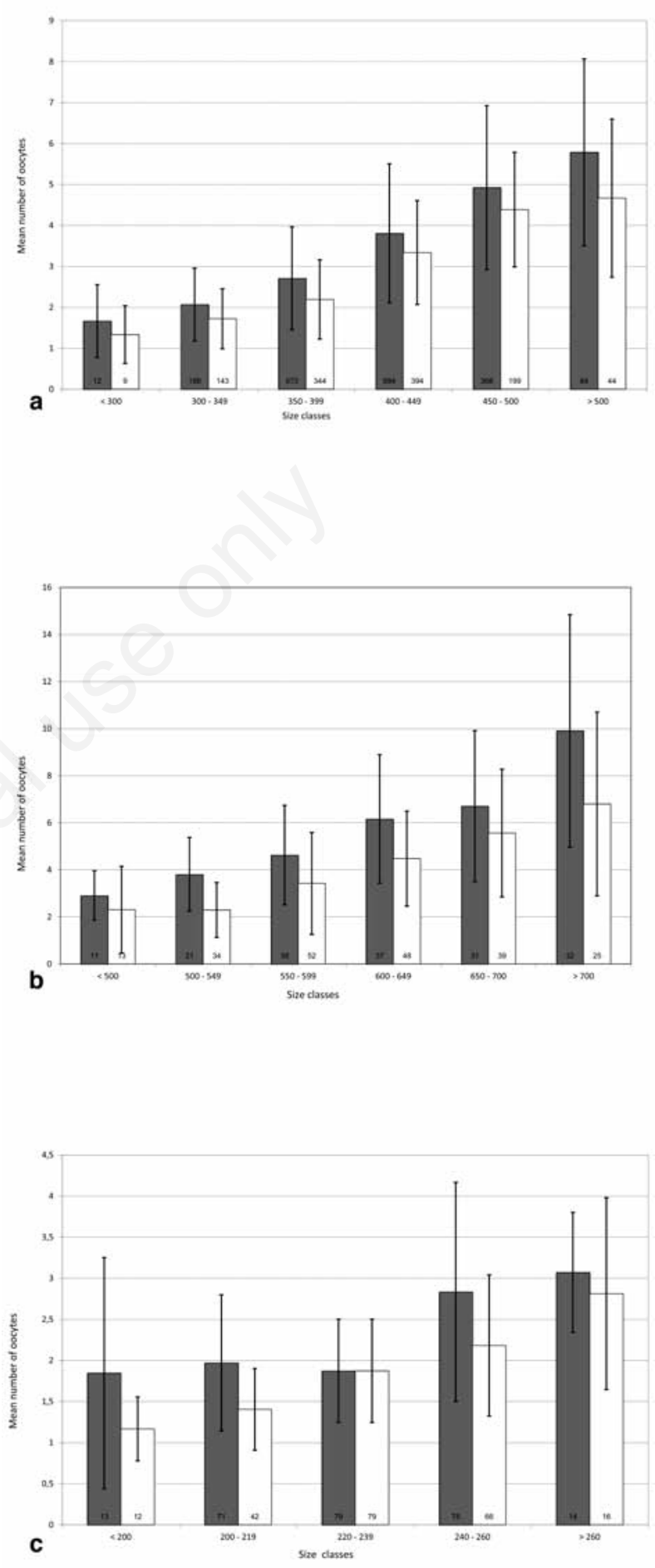

Fig. 3. Size classes of ovigerous specimens and number (mean \pm 1 standard deviation) of immature (grey columns) and mature (white columns) oocytes per ovigerous female. Columns contain the number of specimens examined. a) Macrobiotus hufelandi (total number of specimens $=3040$ ); b) Paramacrobiotus richtersi (total number of specimens $=381$ ); c) Diphascon pingue (total number of specimens $=470$ ). 
Temporal variation in the occurrence of ovigerous specimens and juveniles

In the three species we found ovigerous females and juveniles throughout the year (Figs. 4 and 5). However, percentages (relative to the total number of animals in the respective months) of both showed fluctuations over the years, and percentages of ovigerous females and juveniles were more or less directly opposite, i.e. the more ovigerous specimens, the fewer juveniles were present and vice versa.

Percentages of ovigerous specimens of $M$. hufelandi ranged from 8.17 to $57.83 \%$ relative to the total number of animals. Occurrence of higher percentages $(\geq 40 \%$; high was arbitrarily defined for each species and included only distinct peaks; Fig. 5a) fluctuated over the years, and was found in March to May 2000, February and March 2001, March to May 2002, January to April 2003, and January to May 2004 (Fig. 5a). Percentages of juveniles ranged from 2.74 to $35.26 \%$ and increased with a delay in time with the increasing percentage of ovigerous specimens (Fig. 5a). Percentages of ovigerous specimens in $P$. richtersi ranged from 0 to $26.92 \%$. Higher percentages $(\geq 15 \%)$ were found in May and June 2000, December to April 2001, September, December and June 2002, January, March and May 2003, and February, March, May, June 2004. Percentages of juveniles ranged from 10.26 to $77.23 \%$ (Fig. 5b).

Percentages of ovigerous specimens of $D$. pingue ranged from 7.5 to $60.71 \%$. Higher percentages $(\geq 30 \%)$ were found in May 2000, October, December, April, May 2001, December to February and April to July 2002, October, May, June 2003, and October to December and May 2004. Percentages of juveniles ranged from 0 to $41.9 \%$ (Fig. 5c).

\section{Time of hatching and of development in Macrobiotus hufelandi}

Comparing the number of oocytes (immature, mature) with the number of juveniles, a strong positive correlation was found two to five months later (Tab. 2). Thus, it may be roughly estimated that the time passed from oocytes in early vitellogenesis until hatching varied from three to five months, and the time from oviposition until hatching was two to three months.

\section{Correlation of reproductive traits with mesoclimatic parameters in Macrobiotus hufelandi}

Tab. 3 shows the correlation of the parameters obtained 10, 20, and 30 days before the sampling date. Worth noting is the significant to highly significant negative correlation of the number of oocytes as well as the length and percentage of ovigerous females, and the highly significant positive correlation of the percentage of juveniles, with temperature. Humidity appears to be
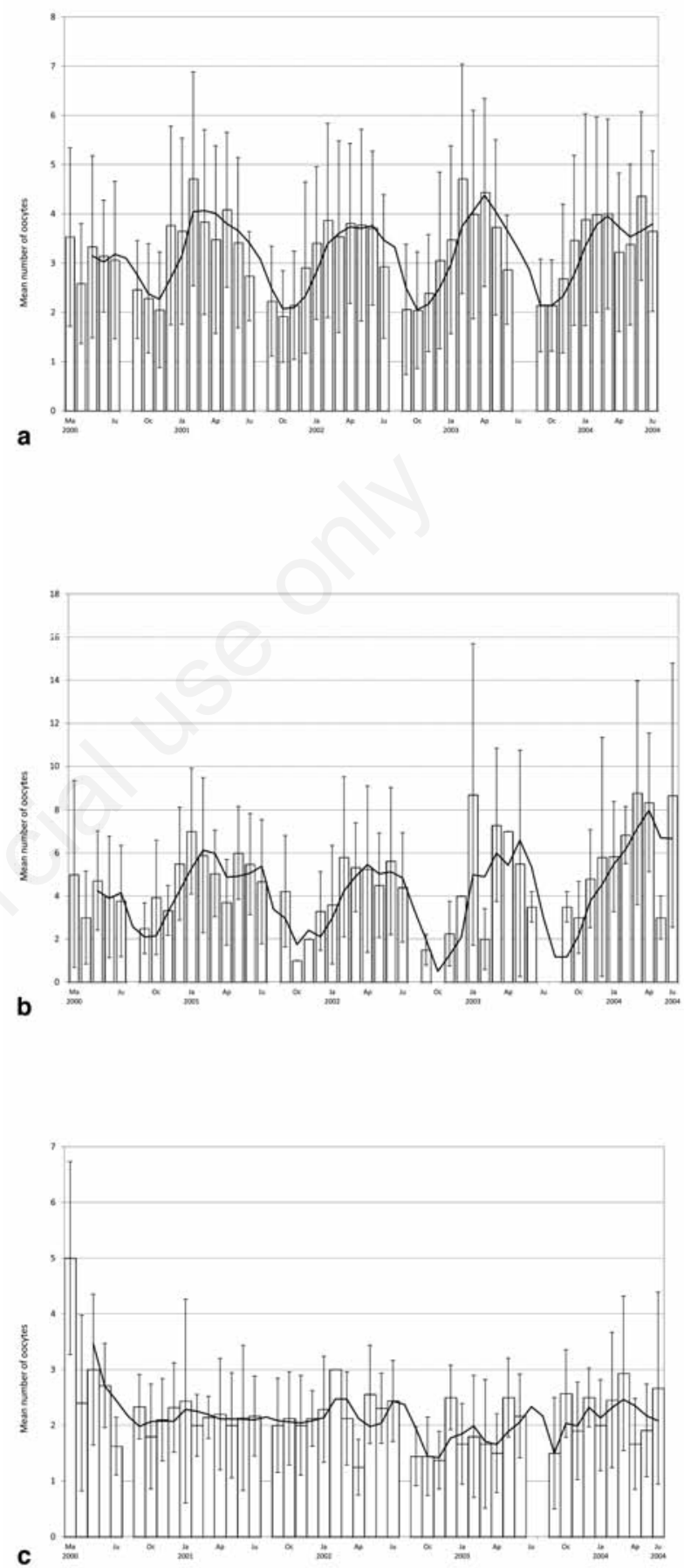

Fig. 4. Number of oocytes (mean \pm 1 standard deviation) (mature and immature) per female from March 2000 to July 2004. a) Macrobiotus hufelandi (number of measured ovigerous females $=3040$, total number of 10,269 oocytes, means $1.92 \pm 0.93-4.71 \pm 2.17$ ); b) Paramacrobiotus richtersi (number of measured ovigerous females $=381$, total number of 1929 oocytes, means $0-8.78 \pm 5.19$ ); c) Diphascon pingue (number of measured ovigerous females $=470$, total number of 1052 oocytes, means $1.25 \pm 0.5$ $5 \pm 1.73$ ). Trend line represents average of 3 months. 
negatively correlated with the number of oocytes and the percentage of juveniles. The sum of hours of sunshine seems to negatively affect body length and percentage of ovigerous females, but produced an increase of juveniles. Temperature and the sum of hours of sunshine seem to have an impact on mortality.

\section{DISCUSSION}

The objective of the present study was to indirectly gain some knowledge on reproduction of tardigrades in their natural habitat and, thereby, broaden knowledge of their life histories. The main results for the three species examined are: i) ovigerous females were found throughout the years with peaks at certain months; ii) the larger the female the more numerous the oocytes (immature and mature); iii) presence of ovigerous adults and juveniles was nearly opposite, i.e. the more adults, the fewer juveniles were found, and a maximum of adults was followed by a maximum of juveniles with some delay and vice versa; iv) oogenesis and development of the young may be considerably delayed compared to data obtained from cultured species; and v) several of the studied parameters could be correlated with the mesoclimate. The most reliable data were from $M$. hufelandi, from which the highest number of individuals was collected, whereas the data set from $P$. richtersi and $D$. pingue may suffer from the relatively low numbers of specimens available, which, however, reflects the generally low number of specimens of these two species in the community (Schuster and Greven, 2007).

Ovigerous specimens as well as juveniles of the three species were found in almost each month of the investigation period (we think this holds true also for the few months in which sampling was not conducted), i.e. reproduction was continuous throughout the years as suggested for a variety of other tardigrades, for example $M$. hufelandi and E. testudo (Morgan, 1977), M. tardigradum (Schütz, 1987), and the aquatic P. kathmanae (Kathman and Nelson, 1987). However, the percentage of ovigerous females within the particular populations showed considerable variation. During the entire investigation period, M. hufelandi showed the highest peaks ( $\geq 40 \%$; arbitrarily selected threshold; see above) between January to June, but months, in which peaks were relatively high, varied considerably during this time and do not exactly mirror the temporal variations of the entire population (Schuster and Greven, 2007). Ovigerous females of $P$. richtersi did not reach such high percentages, and peaks $(\geq 15 \%)$ seemed to be irregularly distributed over the months. The same applies to $D$. pingue, in which peaks $(\geq 30 \%)$ practically included all months in the period of investigation.

Population estimates of tardigrades rarely include data on reproduction. Morgan (1977) examined the number of egg-containing casts of E. testudo in each monthly sample, expressed their number as a percentage of the total
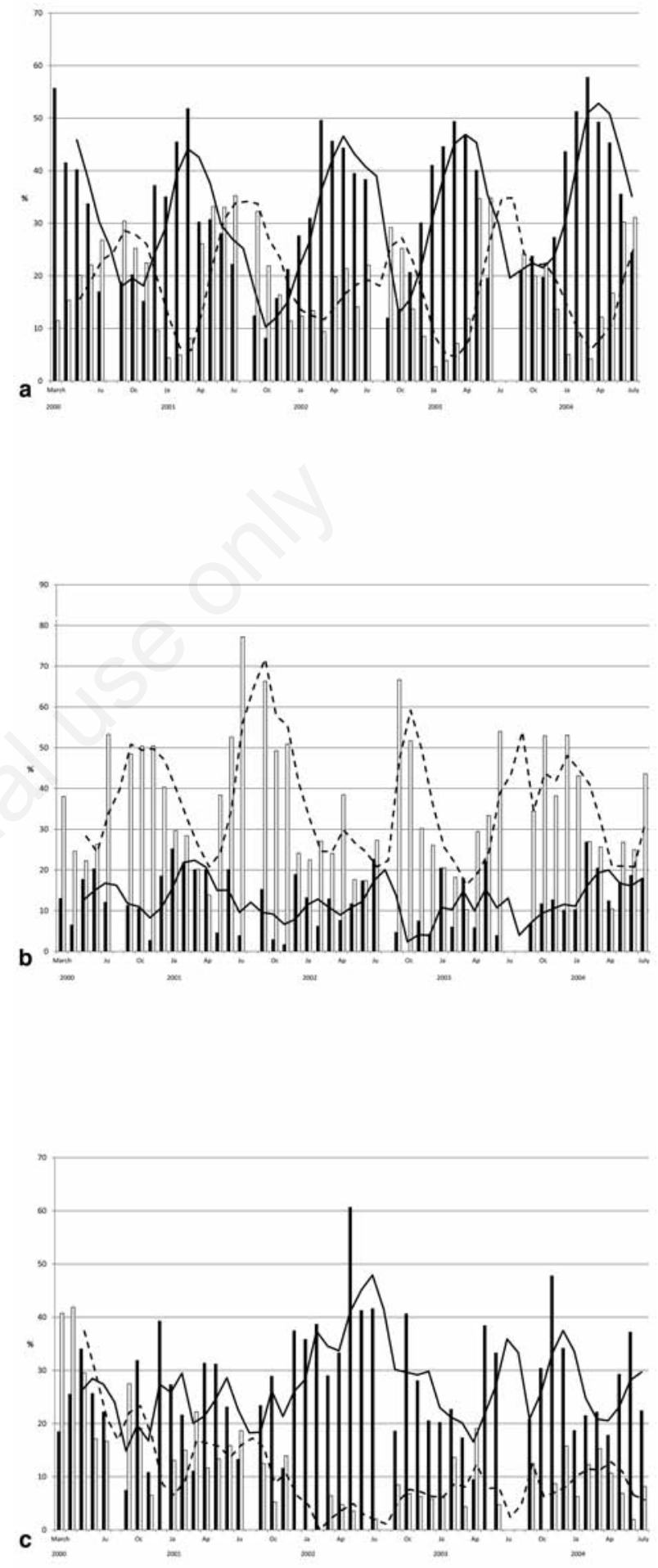

Fig. 5. Percentage of ovigerous (immature and mature oocytes) specimens (black column, solid line) and juvenile specimens (white columns, dotted line) relative to the total number of specimens (n) collected in the respective month from March 2000 to July 2004. a) Macrobiotus hufelandi ( $\mathrm{n}=3200)$; b) Paramacrobiotus richtersi $(\mathrm{n}=416)$; c) Diphascon pingue $(\mathrm{n}=600)$. Trend lines represents average of 3 months. 
population and found a cyclical variation, with highest levels during winter/early spring, which did not match the temporal variation in the population. In $M$. tardigradum a distinct pattern was found neither in the temporal variation of the population, of gravid females, the number of egg-containing casts nor the number of eggs (Schütz, 1987). Kathman and Nelson (1987) studied egg production in the aquatic tardigrade P. kathmanae. Authors could not determine a distinct pattern in abundance, but found the largest individuals (with high reproductive rates) in the winter and early spring and the smallest in summer.

Usually, tardigrades were measured either in asphyxia (Schütz, 1987) or mounted on microscope slides using various embedding media (Morgan, 1977; Kathman and Nelson, 1987) or during walking using time lapse movies (Lemloh et al., 2011) or details were not given (Hohberg, 2006). When measuring specimens after gently pressing the coverslip, we accept some inaccuracies, but our meas- urements are in the range known for the three species, and we could detect size differences. Nevertheless, we abstained from using our data for size-frequency histograms to determine, for example, the number of generations and the lifespan of species. This method uses smaller size classes, but generally is considered as highly subjective (Morgan 1977; Kathman and Nelson, 1987). Instead we used $50 \mu \mathrm{m}$ size classes (and a $20 \mu \mathrm{m}$ size class in the smaller $D$. pingue) and accept the generally expected finding that the larger the female the more numerous the oocytes (immature and mature) (see similar results for $P$. kathmanae; Kathman and Nelson, 1987).

Worth noting is the fact that the average numbers of oocytes during vitellogenesis were significantly larger than the numbers of oocytes after vitellogenesis (mature eggs), thus suggesting oosorption. This phenomenon is widespread in invertebrates and is considered as an adaptive mechanism by which females can redirect nutrients invested in oocytes

Tab. 2. Spearman rank correlation for the number of oocytes in different developmental stages and juveniles in Macrobiotus hufelandi.

\begin{tabular}{lccc}
\hline Time & $\begin{array}{c}\text { Mature and immature } \\
\text { oocytes/juveniles }\end{array}$ & $\begin{array}{c}\text { Immature } \\
\text { oocytes/juveniles }\end{array}$ & $\begin{array}{c}\text { Mature } \\
\text { oocytes/juveniles }\end{array}$ \\
\hline 1. month $(\mathrm{n}=42)$ & 0.01 & -0.22 & $0.30^{*}$ \\
2. month $(\mathrm{n}=41)$ & $0.37^{* *}$ & 0.19 & $0.43^{* *}$ \\
3. month $(\mathrm{n}=40)$ & $0.48^{* *}$ & $0.44^{* *}$ & $0.38^{* *}$ \\
4. month $(\mathrm{n}=39)$ & $0.64^{* *}$ & $0.70^{* *}$ & 0.21 \\
5. month $(\mathrm{n}=38)$ & $0.44^{* *}$ & $0.62^{* *}$ & -0.07 \\
6. month $(\mathrm{n}=38)$ & 0.10 & $0.31^{*}$ & -0.23 \\
\hline
\end{tabular}

n, number of the months considered. "Significant differences $(P<0.05) ;{ }^{* *}$ highly significant differences $(P<0.01)$.

Tab. 3. Correlation matrix of mesoclimatic parameters and the reproductive traits examined (as well as the dead specimens) of Macrobiotus hufelandi in 48 months.

\begin{tabular}{|c|c|c|c|c|c|}
\hline & $\begin{array}{l}\text { Immature } \\
\text { and mature } \\
\text { oocytes (n) }\end{array}$ & $\begin{array}{c}\text { Length of } \\
\text { ovigerous females } \\
(\mu \mathrm{m})\end{array}$ & $\begin{array}{l}\text { Ovigerous } \\
\text { females (\%) }\end{array}$ & $\begin{array}{l}\text { Juveniles } \\
\text { (\%) }\end{array}$ & $\begin{array}{c}\text { Dead specimens } \\
(\%)\end{array}$ \\
\hline \multicolumn{6}{|c|}{ Temperature $\left({ }^{\circ} \mathrm{C}\right)$} \\
\hline 10 days & $-0.28^{*}$ & $-0.43^{* *}$ & $-0.48^{* *}$ & $0.82^{* *}$ & $0.26^{*}$ \\
\hline 20 days & $-0.39^{* *}$ & $-0.44^{* *}$ & $-0.58^{* *}$ & $0.86^{* *}$ & $0.28^{*}$ \\
\hline 30 days & $-0.41^{* *}$ & $-0.44^{* *}$ & $-0.61^{* *}$ & $0.84^{* *}$ & $0.32^{*}$ \\
\hline \multicolumn{6}{|c|}{ Humidity (\%) } \\
\hline 10 days & $-0.31^{*}$ & 0.05 & -0.20 & $-0.33^{*}$ & -0.05 \\
\hline 20 days & $-0.31^{*}$ & -0.01 & -0.20 & $-0.34^{* *}$ & -0.05 \\
\hline 30 days & $-0.32^{*}$ & -0.05 & -0.23 & $-0.35^{* *}$ & -0.12 \\
\hline \multicolumn{6}{|c|}{ Sum of rainfall (mm) } \\
\hline 10 days & -0.12 & 0.19 & -0.06 & 0.06 & -0.02 \\
\hline 20 days & -0.15 & 0.19 & -0.12 & -0.06 & 0.05 \\
\hline 30 days & -0.08 & $0.32^{*}$ & -0.06 & -0.08 & 0.12 \\
\hline \multicolumn{6}{|c|}{ Sum of sunshine $(\mathrm{h})$} \\
\hline 10 days & -0.1 & $-0.26^{*}$ & -0.22 & $0.69^{* *}$ & 0.21 \\
\hline 20 days & -0.13 & $-0.25^{*}$ & $-0.27^{*}$ & $0.72^{* *}$ & 0.24 \\
\hline 30 days & -0.15 & $-0.31^{*}$ & $-0.31^{*}$ & $0.75^{* *}$ & $0.26^{*}$ \\
\hline
\end{tabular}

"Significant differences $(P<0.05)$; **highly significant differences $(P<0.01)$. 
into survival when conditions for reproduction are poor to optimise fitness in hostile environments (Adiyodi and Adiyodi, 1983; Bertolani, 1983). To our knowledge, this phenomenon has not been studied in tardigrades.

Maximal numbers of mature eggs counted by us appear to be lower than known from cultures of these or related species, i.e. up to 15 in M. hufelandi (Baumann, 1970), up to 27 in a large specimen ( $860 \mu \mathrm{m}$ in length) of $P$. richtersi (Hohberg, 2006), up to 44 in a parthenogenetic field specimen of $P$. richtersi (Altiero et al., 2010), and up to eight in Diphascon cf. scoticum (Altiero and Rebecchi, 2001). The number of juveniles of the three species examined herein seems to appear in a wave-like pattern. Compared to the predominantly algae-feeding species $M$. hufelandi and $D$. pingue, the carnivorous $P$. richtersi reached exceptionally high percentages of juveniles, which always exceeded the percentage of ovigerous females relative to the total number of specimens collected. A high increase in juveniles was accompanied by a decrease in the percentage of ovigerous females and vice versa. The wave-like pattern and the opposite time of development of juveniles and ovigerous females was observed also in $M$. hufelandi and $D$. pingue (in this species, however, less distinct), but in both species the percentage of juveniles never exceeded the percentage of ovigerous females. This suggests different reproductive and survival strategies not yet explained. At the moment we can not entirely exclude the possibility that the above mentioned wave-like pattern and the opposite presence of juveniles and ovigerous females may be caused by specimens between the moss and the soil, as species like P. richtersi are frequently found in high numbers in the soil (Hallas and Yeates, 1972; Hohberg, 2006; Bartels and Nelson, 2007). Vertical shifting may be an active process, e.g. in response to changing moisture conditions (Wright, 1991; Nelson and Adkins, 2001) or passive (e.g. by rinsing out of the moss cushion; Greven and Schüttler, 2001). However, if so, events leading to these movements must occur more or less periodically and selectively.

As expected, developmental times may be considerably delayed in the natural habitat. Our rough calculation for $M$. hufelandi suggests several months from early vitellogenesis until hatching and a somewhat shorter time from oviposition to hatching. We think that our specimens classified as juveniles were largely hatchlings or slightly older.

Life history data of Tardigrada such as life span, body growth, egg developmental times, and generation time either were indirectly developed from population studies (Franceschi et al., 1962-1963; Morgan, 1977) or directly by observing tardigrades in cultures. Data may vary depending on temperature and species. In cultures developmental and generation times are in most cases considerably shorter than those calculated by us; in $M$. hufelandi egg development takes 10 days and embryonic development 26-31 days (Baumann, 1970; Altiero and
Rebecchi, 2001; Suzuki, 2003; Hohberg, 2006; Horikawa et al., 2008; Lemloh et al., 2011). Extended times of development may be explained among others by the more or less periodic dehydration of the moss (Marcus, 1929), in which development stops or is considerably slowed down, or the absence of favourable temperatures combined with specific humidities. Most of such factors finally depend on the mesoclimate, but microclimatic factors (hitherto unknown) also determined by the structure of the habitat (see the discussion in Schuster and Greven, 2007; Schuster et al., 2009) and species-specific factors have to be considered too. It has been shown that also eggs and developmental stages of tardigrades can withstand desiccation and low temperatures (Bertolani et al., 2004; Schill and Fritz, 2008; Guidetti et al., 2011). Hohberg (2006) has documented temperature-dependent development in cultures of $P$. richtersi with the shortest generation time ( 43 days) at $20^{\circ} \mathrm{C}$, but noted high variability in egg development times. More, recently Altiero et al. (2010) demonstrated a tremendous variability in the egg development time in cultured P. richtersi, with the time ranging from 30 to 90 days, and they distinguished subitaneous, delayed-hatching eggs and diapause resting eggs, a phenomenon that might be more widespread among tardigrades (Altiero et al., 2010).

\section{CONCLUSIONS}

Many studies have tried to determine correlations between tardigrade numbers and mesoclimatic factors, in particular temperature, humidity, and rainfall, but with various success (Romano et al., 2001; Schuster and Greven, 2007). Surely, the mesoclimate is a determining factor and correlations between mesoclimatic variables and tardigrade populations exist. However, these variables should act indirectly rather than directly, and they may be often superimposed by variables in the microenvironment, and therefore are not easy or not to interpret (see literature cited above). Generally, the population of M. hufelandi was correlated with temperature (Schuster and Greven, 2007), which generally may also affect vitellogenesis, the number of eggs, and intervals of molting cycles. The percentage of juveniles relative to the total number of collected animals is positively correlated with temperature, whereas the sum of days of sunshine has a negative (ovigerous females) or positive (juveniles) impact similar to that of temperature. The rainfall was insignificant in an environment generally characterized by a high humidity (Schuster, 2003; Schuster and Greven, 2007).

\section{REFERENCES}

Adiyodi KG, Adiyodi RG, 1983. Reproductive biology of invertebrates. Oogenesis, oviposition, oosorption. 1. John Wiley \& Sons, Chichester: 770 pp.

Altiero T, Bertolani R, Rebecchi L, 2010. Hatching phenology 
and resting eggs in tardigrades. J. Zool. 280:290-296.

Altiero T, Rebecchi L, 2001. Rearing tardigrades: results and problems. Zool. Anz. 240:217-221.

Backhaus K, Erichson B, Plink, W, Weiber R, 1966. Multivariate Analysemethoden. Springer Verlag, Berlin: $230 \mathrm{pp}$.

Bartels PJ, Nelson DR, 2007. An evaluation of species richness estimators for tardigrades of the Great Smoky Mountains National Park, Tennessee and North Carolina, USA. J. Limnol. 66(Suppl. 1):104-110.

Baumann H, 1970. [Lebenslauf und Lebensweise von Macrobiotus hufelandi Schultze (Tardigrada)]. [Article in German]. Veröff. Übers. Bremen 4:29-43.

Bertolani R, 1971. [Partenogenesi geografica triploide in un tardigrado (Macrobiotus richtersi)]. [Article in Italian]. Atti Accad. Naz. Lincei Ren. Ser. 8a 50:487-489.

Bertolani R, 1975. Cytology and systematics in Tardigrada. Mem. Ist. Ital. Idrobiol. 32(Suppl.):17-35.

Bertolani R, 1983. Tardigrada, p. 431-441. In: K.G. Adiyodi and R.G. Adiyodi (eds.), Reproductive biology of invertebrates. 1: Oogenesis, oviposition, oosorption. John Wiley \& Sons.

Bertolani R, Guidetti R, Jönsson KI, Altiero T, Boschini D, Rebecchi L, 2004. Experiences with dormancy in tardigrades. J. Limnol. 63(Suppl. 1):16-25.

Bertolani R, Rebecchi L, 1993. A revision of the Macrobiotus hufelandi group (Tardigrada, Macrobiotidae) with some observations on the taxonomic characters of eutardigrades. Zool. Scripta 22:127-152.

Biserov VI, 1990. [On the revision of the genus Macrobiotus. The subgenus Macrobiotus s. str.: a new systematic of the hufelandi group (Tardigrada, Macrobiotidae)]. [Article in Russian]. Communication 1. Zool. Zh. 69:5-17.

Franceschi T, Loi ML, Pierantoni R, 1962-1963. [Risultati di una prima indagine ecologica condotta su popolazioni di Tardigradi]. [Article in Italian]. Boll. Mus. Ist. Univ. Genova 32:69-93.

Grabowski B. 1995. [Ökologische Untersuchungen an moosbewohnenden Bärtierchen (Tardigrada) mit einem Bericht über drei neue Arten für Deutschland]. [Article in German]. Acta Biol. Benrodis 7:77-98.

Greven H, Schüttler L, 2001. How to crawl and dehydrate on moss. Zool. Anz. 240:341-344.

Guidetti R, Altiero T, Rebecchi L, 2011. On dormancy strategies in tardigrades. J. Insect Physiol. 57:567-576.

Guidetti R, Bertolani R, Nelson D, 1999. Ecological and faunistic studies in tardigrades in leaf litter of beech forests. Zool. Anz. 238:215-223.

Hallas TE, Yeates GW, 1972. Tardigrada of the soil and litter of a Danish beech forest. Pedobiologia 12:287-304.

Hohberg K, 2006. Tardigrade species composition in young soils and some aspects on life history of Macrobiotus richtersi $\mathrm{J}$. Murray, 1911. Pedobiologia 50:267-274.

Horikawa DD, Kunieda T, Abe W, Watanabe M, Nakahara Y, Yukuhiro F, Sakashita T, Hamada N, Wada S, Funayama T, Katagiri C, Kobayashi Y, Higashi S, Okuda T, 2008. Estab- lishment of a rearing system of the extremotolerant tardigrade Ramazzottius varieornatus: a new model animal for astrobiology. Astrobiology 8:549-556.

Jennings PG, 1979. The Signy Island terrestrial reference sites: X. Population dynamics of Tardigrada and Rotifera. Br. Antarct. Surv. Bull. 47:89-105.

Kathman RD, Nelson DR, 1987. Population trends in the aquatic tardigrade Pseudobiotus augusti (Murray), p. 155-168. In: R. Bertolani (ed.), Biology of Tardigrades. Selected Symposia and Monographs. U.Z.I., Mucchi ed.

Lemloh M-L, Brümmer F, Schill RO, 2011. Life-history traits of the bisexual tardigrades Paramacrobiotus tonollii and Macrobiotus sapiens. J. Zool. Syst. Evol. Res. 49(Suppl. 1):58-61.

Marcus E, 1929. [Tardigrada], p. 1-608. In: H.G. Bronn (ed.), [Klassen und Ordnungen des Tierreichs. 5, IV, 3]. [Book in German]. Akademische Verlagsgesellschaft ed.

Morgan CI, 1977. Population dynamics of two species of Tardigrada, Macrobiotus hufelandii (Schultze) and Echiniscus (Echiniscus) testudo (Doyère), in roof moss from Swansea. J. Anim. Ecol. 46:236-279.

Nelson DR, Adkins RG, 2001. Distribution of tardigrades within a moss cushion: do tardigrades migrate in response to changing moisture conditions? Zool. Anz. 240:493-500.

Nelson DR, Marley NJ, Bertolani R, 1999. Re-description of the genus Pseudobiotus (Eutardigrada, Hypsibiidae) and the new type species Pseudobiotus kathmanae sp. n. Zool. Anz. 238:311-317.

Romano FA III, Barreras-Borrero B, Nelson DR, 2001. Ecological distribution and community analysis of Tardigrada from Choccolocco Creek, Alabama. Zool. Anz. 240:535-541.

Schill RO, Fritz GB, 2008. Desiccation tolerance in embryonic stages of the tardigrade. J. Zool. 276:103-107.

Schuster R, 2003. Faunistische und ökologische Untersuchungen an Tardigraden des Schwarzwalds (Deutschland). Acta Biol. Benrodis 12:147-192.

Schuster R, Greven H, 2007. A long-term study of population dynamics of tardigrades in the moss Rhytidiadelphus squarrosus (Hedw.) Warnst. J. Limnol. 66(Suppl. 1):141-151.

Schuster R, Spiertz I, Lösch R, Greven H, 2009. Microclimate and vertical distribution of tardigrades in a moss cushion, $p$. 59. In: R.O. Schill, K. Hohberg and H. Greven (eds.), $11^{\text {th }}$ International Symposium on Tardigrada. Conference Guide, 3-6 August 2009, Tübingen, Germany.

Schütz G, 1987. A one-year study on the population-dynamics of Milnesium tardigradum Doyère in the lichen Xanthoria parietina (L.) Th.Fr., p. 217-228. In: R. Bertolani (ed.), Biology of Tardigrades. Selected Symposia and Monographs U.Z.I., 1. Mucchi Editore.

Suzuki AC, 2003. Life history of Milnesium tardigradum Doyère (Tardigrada) under a rearing environment. Zool. Sci. 20:49-57.

Wright JC, 1991. The significance of four xeric parameters in the ecology of the terrestrial Tardigrada. J. Zool. 224:59-77. 